\title{
PENGARUH KEPEMIMPINAN MOTIVASI DAN LINGKUNGAN KERJA TERHADAP PRESTASI KARYAWAN PT ASURANSI GENERALLI \\ YOGYAKARTA \\ JURNAL
}

\section{Umi Kalsum}

\begin{abstract}
ABSTRAK
Penelitian ini memiliki tujuan untuk menguji pengaruh Kepemimpinan terhadap Prestasi karyawan PT. Asuransi Generalli yogyakarta. Untuk mengetahui pengaruh Motivasi terhadap prestasikaryawan PT. Asuransi Generalli yogyakarta. Untuk mengetahui pengaruh Lingkungan kerja terhadap Prestasi karyawan PT. Asuransi Generalli yogyakarta. Untuk mengetahui variabel yang paling dominan pengaruhnya terhadap prestasi karyawan PT. Asuransi Generalli yogyakarta.

Hasil pengujian persamaan Y hipotesis 1 menunjukkan bahwa Nilai signifikansi dari variabel kepemimpinan (X1) adalah 0,733 yang berarti bahwa model tidak signifikan karena signifikansi $>$ 0,05. Dengan demikian Ha ditolak dan Ho diterima. Oleh karena itu, dapat diartikan bahwa kepemimpinan tidak berpengaruh secara positif dan signifikan terhadap prestasi karyawan. Hipotesis 2 menunjukkan bahwa motivasi (X2) adalah sebesar .000 sehingga dapat dikatakan model ini signifikan karena signifikansi $<0,05$. Dengan demikian, Ho ditolak dan Ha diterima. Hal ini dapat diartikan bahwa Motivasi kerja berpengaruh secara signifikan terhadap prestasi karyawan. Hipotesis 3 lingkungan kerja (X3) sebesar 0,456 sehingga dapat dikatakan model ini tidak signifikan karena signifikansi $<0,05$. Dengan demikian, Ho diterima dan Ha ditolak. Hal ini dapat diartikan bahwa lingkungan kerja berpengaruh secara signifikan terhadap prestasi karyawan. Hasil uji $\mathrm{F}$ dengan sifnifikansi 0.0001 karena probabilitas lebih kecil dari 0.05 maka model regresi dapat digunakan untuk memprediksi prestasi kerja (Y). Ini menunjukkan bahwa pengaruh kepemimpinan, motivasi kerja, dan lingkungan kerja secara simultan berpengaruh terhadap prestasi karyawan PT. Asuransi Generalli yogyakarta.
\end{abstract}

Kata kunci : Kepemimpinan, motivasi, lingkungan kerja, prestasi karyawan.

\section{Pendahuluan}

Salah satu keberhasilan karyawan adalah pencapaian prestasi kerja merupakan ukuran keberhasilan atau kesuksesan seseorang karyawan. Karyawan itu sendiri dalam melaksanakan tugas atau pekerjaan selalu ingin mengetahui hasilnya baik atau buruk, dan ada kemajuan atau kemunduran. Perusahaan harus dapat menciptakan strategi pemberdayaan karyawan yang sesuai, agar setiap karyawan dalam perusahaan membuat komitmen pribadi terhadap tujuan yang direncanakan. Hal ini memerlukan perhatian khusus terhadap berbagai faktor yang berkaitan dengan peningkatan suatu prestasi kerja, seperti halnya seorang pemimpin, motivasi, lingkungan kerja yang ada di suatu perusahaan. Kepemimpinan (leadership) dapat dikatakan sebagai cara dari seorang pemimpin (leader) dalam mengarahkan, 


\section{JURNAL MANAJEMEN VOL. 5 NO. 2 DESEMBER 2015}

mendorong, dan mengatur seluruh unsurunsur di dalam organisasi atau perusahaannya untuk mencapai suatu tujuan perusahaan yang diinginkan sehingga menghasilkan prestasi dalam bekerja. Kepemimpinan sangat mempengaruhi sikap bawahan. Apabila pimpinan kurang memberikan pengarahan dan bimbingan pada bawahan, maka akan tumbuh hubungan kerja yang bersifat kaku, dan akan terjadi suasana kerja yang kurang menyenangkan.

Motivasi dalam suatu perusahaan di perlukan, untuk meningkatkan atau menjaga etos kerja para karyawan agar tetap gigih dan giat dalam bekerja guna meningkatkan atau menjaga produktifitas kerja. Semangat para pekerja tersebut sangat dibutuhkan suatu perusahaan karena dengan semangat yang tinggi para karyawan dapat bekerja dengan segala daya dan upaya yang mereka miliki (tidak setengah-setengah) sehingga produktifitasnya maksimal dan memungkinkan terwujutnya tujuan yang ingin dicapai.

Lingkungan kerja yang nyaman seperti struktur kerja, tanggung jawab kerja, perhatian dan dukungan pemimpin, kerja sama antar kelompok, dan adapun kelancaran komunikasi. Hal ini sangat berpengaruh besar terhadap kinerja karyawan PT. Asuransi Generalli
Yogyakarta. Para karyawan akan merasa nyaman dalam bekerja, sehingga meningkatkan kerjanya apabila lingkungan kerja yang memadai, sesuai dengan apa yang mereka harapkan.

\section{Kajian Pustaka dan Hipotesis}

\section{Kepemimpinan}

Kepemimpinan sangat diperlukan bagi suatu organisasi dalam menentukan kemajuan dan kemunduran organisasi, serta tidak ada organisasi yang tidak dapat maju tanpa kepemimpinan yang baik (Mas'ud,2004,61-68).

Tanpa

kepemimpinan organisasi hanyalah merupakan kumpulan orang-orang yang tidak teratur dan kacau balau. Kepemimpinan akan merubah sesuatu yang potensial menjadi kenyataan. Dengan demikian keberadaan kepemimpinan dalam organisasi adalah sangat penting dalam mencapai tujuan dan kemajuan organisasi.

Robbins (2008: 93) mengartikan kepemimpinan adalah kemampuan untuk mempengaruhi suatu kelompok kearah tercapainya tujuan. Lebih lanjut lagi Nimran (2004:64) mendefinisikan kepemimpinan (leadership) yaitu suatu proses mempengaruhi perilaku orang lain agar berperilaku seperti yang dikehendaki. Kemudian Mulyadi dan Rivai (2009:2) menjelaskan bahwa kepemimpinan adalah 
proses mempengaruhi dalam menentukan tujuan organisasi, memotivasi perilaku pengikut untuk mencapai tujuan, mempengaruhi untuk memperbaiki budaya pengikut, serta proses mengarah kedalam aktivitas-aktivitas positif yang ada hubungannya dengan pekerjaan dalam organisasi.

Menurut Mulyadi dan Rivai (2009:3) pemimpin dalam suatu organisasi dalam memberikan pengaruh kepada bawahannya lebih bersifat formal, yaitu berdasarkan posisi yang dimiliki pemimpin dalam organisasi. Dengan demikian pemimpin dalam suatu organisasi sangat ditentukan oleh statusnya, yakni sebagai pimpinan formal. Pimpinan formal sendiri adalah seseorang yang ditunjuk sebagai pemimpin, atas dasar keputusan dan pengangkatan resmi untuk memangku jabatan dalam struktur organisasi, dengan segala hak dan kewajiban yang melekat berkaitan dengan posisinya

\section{Motivasi}

Untuk memberikan dorongan dan menggerakkan orang-orang agar mereka bersedia bekerja semaksimal mungkin, perlu diusahakan adanya komunikasi dan peran serta dari semua pihak yang bersangkutan. Motivasi menunjukkan agar manejer mengetahui bagaimana memberikan informasi yang tepat kepada bawahan agar mereka menyediakan waktunya guna melakukan usaha yang di perlukan untuk memperoleh saran-saran dan rekomendasi-rekomendasi mengenai masalah yang di hadapi. Untuk itu diperlukan keahlian manajer untuk memberikan motivasi kepada bawahaannya agar bisa bekerja sesuai dengan pengarahan yang di berikan. Manullang (2004) menyatakan bahwa motivasi adalah memberikan daya perangsang kepada karyawan yang bersangkutan agar karyawan tersebut bekerja dengan segala daya dan upayanya.

Menurut Ishaq Arep dan Henri Tanjung (2004:12) SL Triyaningsih dan Wiharso motivasi sebagai suatu yang pokok, yang menjadi dorongan bagi seseorang untuk bekerja. SL Triyaningsih dan Wiharso juga mengutip pernyataan Stephan P. Robbins (2006:213) motivasi sebagai proses yang ikut menentukan intesitas arah dan ketekunan individu dalam usaha mencapai sasaran.

\section{Lingkungan kerja}

Lingkungan kerja dalam suatu perusahaan sangat penting untuk diperhatikan manajemen. Meskipun lingkungan kerja tidak melaksanakan proses produksi dalam suatu perusahaan, namun lingkungan kerja mempunyai pengaruh lansung terhadap para karyawan yang melaksanakan proses produksi tersebut. Lingkungan kerja adalah suasana 


\section{JURNAL MANAJEMEN VOL. 5 NO. 2 DESEMBER 2015}

dimana karyawan melakukan aktivitas setiap harinya. Lingkungan kerja yang kondusif memberikan rasa aman dan memungkinkan karyawan untuk dapat bekerja optimal. Jika karyawan nmenyenangi lingkungan kerja dimana dia bekerja, maka karyawan tersebut akan betah ditempat kerjanya, melakukan aktivitasnya sehingga waktu kerja dipergunakan secara efektif. Sebaliknya lingkungan kerja yang tidak memadai akan dapat menurunkan kinerja karyawan. Beberapa ahli mendifinisikan lingkungan kerja antara lain sebagai berikut:

Menurut (Nitisemito dalam Nuraini 2013:97) lingkungan kerja adalah segala sesuatu yang ada disekitar karyawan dan dapat mempengaruhi dalam menjalankan tugas yang dibebankan kepadanya.

Menurut Mangkunegara (2004: 68), lingkungan kerja mempunyai hubungan yang sangat erat terhadap kinerja karyawan, motif berprestasi yang perlu dimiliki oleh karyawan harus ditumbuhkan dari dalam diri sendiri dan dari lingkungan kerja, karena motif berprestasi yang ditumbuhkan dari dalam diri sendiri akan membentuk suatu kekuatan diri dan jika situasi lingkungan kerja turut menunjang maka pencapaian kinerja akan lebih mudah.

Prestasi kerja
Pengertian penilaian prestasi kerja menurut Lloyd L. Byarsdan Leslie W. Rue (2004:251) adalah Performance appraisal is a process of determining and communicating to an employee how he or she is performing on the job, and ideally, establishing a plan of improvement. Penilaian prestasi kerja karyawan adalah proses untuk menentukan dan mengkomunikasikan kepada karyawan tentang bagaimana performanya dalam melakukan pekerjaannya dan idealnya, membuat rencana untuk membangun kariernya. Sedangkan Menurut Hasibuan (2008:94) menyatakan bahwa: "Prestasi kerja adalah suatu hasil kerja yang dicapai seseorang dalam melaksanakan tugastugas yang dibebankan kepadanya yang didasarkan atas kecakapan, pengalaman, dan kesungguhan serta waktu”. Selanjutnya Rivai (2004:309) mengatakan bahwa :

"Prestasi Kerja merupakan suatu fungsi dari motivasi dan kemampuan”. Pengukuran prestasi kerja berfungsi sebagai target atau sasaran, sebagai input yang digunakan pegawai dalam mengarahkan usahanya melalui serangkaian prioritas. Pengukuran dan penilai prestasi kerja merupakan usaha membandingkan hasil kerja, penampilan, dan target yang harus di 
laksanakan dengan standar kerja dengan penampilan dan target yang di tentukan.

Dalam penelitian ini penulis mengajukan beberapa hipotesis, antara lain:

1. Ada pengaruh kepemimpinan terhadap prestasi karyawan PT. Asuransi Generalli yogyakarta.

2. Ada pengaruh motivasi terhadap prestasi karyawan PT. Asuransi Generalli yogyakarta.

3. Ada pengaruh lingkungan kerja terhadap prestasi karyawan PT. Asuransi Generalli Yogyakarta.

\section{Metode Penelitian}

Populasi dalam penelitian ini adalah karyawan PT. Generalli Yoyakarta yang berjumlah 80 karyawan.

\section{HASIL DAN PEMBAHASAN}

Hasil pengujian hipotesis 1 menunjukkan bahwa Nilai signifikansi dari variabel kepemimpinan (X1) adalah 0,733 yang berarti bahwa model tidak signifikan karena signifikansi $>0,05$. Dengan demikian Ha ditolak dan Ho diterima. Oleh karena itu, dapat diartikan bahwa kepemimpinan tidak berpengaruh secara positif dan signifikan terhadap prestasi karyawan. Hipotesis 2 menunjukkan bahwa motivasi (X2) adalah sebesar .000 sehingga dapat dikatakan model ini signifikan karena signifikansi $<0,05$. Dengan demikian, Ho ditolak dan $\mathrm{Ha}$ diterima. Hal ini dapat diartikan bahwa Motivasi kerja berpengaruh secara signifikan terhadap prestasi karyawan. Hipotesis 3 lingkungan kerja (X3) sebesar 0,456 sehingga dapat dikatakan model ini tidak signifikan karena signifikansi $<0,05$. Dengan demikian, Ho diterima dan $\mathrm{Ha}$ ditolak. Hal ini dapat diartikan bahwa lingkungan kerja berpengaruh secara signifikan terhadap prestasi karyawan.

\section{KESIMPULAN}

1. Penelitian dengan regresi berganda menghasilkan sifnifikansi 0.0001 karena probabilitas lebih kecil dari 0.05 maka model regresi dapat digunakan untuk memprediksi prestasi kerja (Y). Ini menunjukkan bahwa pengaruh kepemimpinan, motivasi kerja, dan lingkungan kerja secara simultan berpengaruh terhadap prestasi karyawan PT. Asuransi Generalli yogyakarta.

2. Hasil pengujian persamaan $\mathrm{Y}$ hipotesis 1 menunjukkan bahwa Nilai signifikansi dari variabel kepemimpinan (X1) adalah 0,733 yang berarti bahwa model tidak signifikan karena signifikansi > 0,05. Dengan demikian Ha ditolak dan Ho diterima. Oleh karena itu, 


\section{JURNAL MANAJEMEN VOL. 5 NO. 2 DESEMBER 2015}

dapat diartikan bahwa kepemimpinan tidak berpengaruh secara positif dan signifikan terhadap prestasi karyawan. Hipotesis 2 menunjukkan bahwa motivasi (X2) adalah sebesar .000 sehingga dapat dikatakan model ini signifikan karena signifikansi $<0,05$. Dengan demikian, Ho ditolak dan $\mathrm{Ha}$ diterima. Hal ini dapat diartikan bahwa Motivasi berpengaruh secara signifikan terhadap prestasi karyawan. Hipotesis 3 lingkungan kerja (X3) sebesar 0,456 sehingga dapat dikatakan model ini tidak signifikan karena signifikansi $<0,05$. Dengan demikian, Ho diterima dan Ha ditolak. Hal ini dapat diartikan

\section{DAFTAR PUSTAKA}

Anwar Prabu Mangkunegara. (2009). Evaluasi Kinerja Sumber Daya Manusia. Bandung: Penerbit Refika Aditama.

Arikunto, Suharsimi. (2006). Prosedur Penelitian Suatu Pendekatan Praktik. Jakarta : Rineka Cipta.

Arep, Ishak dan Hendri Tanjung. (2003). Manajemen Sumber Daya Manusia. Jakarta: Universitas Trisakti.

Handoko, H. (1998). Manajemen Personalia dan Sumber Daya Manusia. Edisi 2, Yogyakarta: BBPE.

Keith Davis And John W. Newstrom, (1993). Perilaku Dalam Organisasi, Erlangga.

Kartono, kartini, Dr. 2002. Psikologi Sosial Untuk Manajemen, Perusahaan dan Industri. Jakarta: PT. Raja Grafindo Persada. bahwa lingkungan kerja berpengaruh secara signifikan terhadap prestasi karyawan.

3. Dari hasil uji hipotesis tersebut dapat diambil kesimpulan bahwa variabel kepemimpinan tidak berpengaruh secara positif dan signifikan terhadap prestasi karyawan, variabel motivasi berpengaruh secara positif dan signifikan terhadap prestasi karyawan, sedangkan lingkungan kerja berpengaruh secara signifikan terhadap prestasi karyawan, dengan demikian dapat dikatakan bahwa variabel motivasi dan lingkungan kerja memiliki pengaruh yang lebih kuat terhadap prestasi karyawan dari pada variabel kepemimpinan.

Mardiana, (2005). Manajemen Produksi, Jakarta: Penerbit Badan Penerbit IPWI.

Mas'ud, Fuad. (2004). Survai diagnosis organisasional: konsep \& aplikasi. Semarang: Badan Penerbit Universitas Diponegoro.

Nawawi, Hadari. (2006). Evaluasi dan Manajemen Kinerja di Lingkungan Perusahaan dan Industri. Yogyakarta: Gadjah Mada University Press.

Nurhayati, Dina. (2008). Pengaruh Gaya Kepemimpinan Dan Iklim Kerja Terhadap Kinerja Karyawan Perusahaan Kerajinan AKP CRAFT Bantul. Skripsi. Universitas Negeri Yogyakarta.

Nimran, Umar, (2004). Perilaku organisasi, cetakan ketiga, Surabaya: CV. Citra Media. 
Prawirosentono, Suryadi. (2000). kebijakan kinerja karyawan. Yogyakarta: BPPE.

Robbins. P.S., (2002). Prinsip-prinsip Perlaku Organisasi. Edisi kelima, Jakarta: Penerbit Erlangga.

Sedarmayanti, (2007). Sumber Daya Manusia dan Produktivitas Kerja, Bandung: Penerbit Mandar Maju.

Sarwono, Sarlito Wirawan. (2005). Psikologi Lingkungan, Jakarta: Penerbit PT.Gramedia Grasindo.

Simamora, Henry, (2004). Manajemen Sumber Daya Manusia, Yogyakarta: Penerbit STIE YKPN.
Sholeha, Euis. dan Suzy. 1996. Kepemimpinan Yang Efektif, Tinjauan dan Implementasinya Bagi Pencapaian Tujuan Organisasi. Jurnal Gema Stikubank. Hal: 45-56.

Sekaran, Uma. (2007). Research Methods for Business (Terjemahan), Edisi 4, Jilid 1. Jakarta: Salemba Empat.

Veithzal Rivai dan Deddy Mulyadi. 2009. Kepemimpinan dan Perilaku Organisasi. Jakarta: PT Rajagrafindo Persada. 